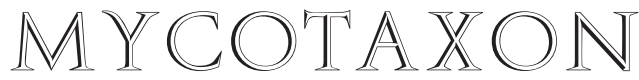

Volume 125, pp. 11-35

\title{
Five Leptonia species from New South Wales and Queensland, Australia
}

\author{
David L. Largent ${ }^{1 *}$, Sarah E. Bergemann ${ }^{2}$, Sandra E. Abell-Davis ${ }^{3}$, \\ Kerri L. Kluting ${ }^{2}$, \& Griffin A. Cummings ${ }^{2}$ \\ ${ }^{1}$ Biological Sciences, Humboldt State University, 1 Harpst St, Arcata CA 95521 USA \\ ${ }^{2}$ Biology Department, Middle Tennessee State University, \\ PO Box 60, Murfreesboro TN 37132 USA \\ ${ }^{3}$ School of Marine and Tropical Biology, Australian Tropical Herbarium and Centre for Tropical \\ Environmental \& Sustainability Science, James Cook University, \\ PO Box 6811, Cairns QLD 4870 AU \\ *Correspondence to: mrp@humboldt1.com
}

\begin{abstract}
Aвstract - Descriptions and illustrations are provided for five Leptonia species. Three species are new to science: Leptonia boardinghousensis possesses unusual basidiomes colours, L. ambigua has subisodiametric basidiospores that atypically have obscure angles at the apex and a lignicolous habit, and L. omphalinoides is distinguished by its lignicolous omphalinoid tiny basidiomes. Two species were previously reported: L. poliopus from Europe and L. umbraphila comb. nov from the Seychelles.
\end{abstract}

KeY wORDS - Basidiomycota, Entolomataceae, mtSSU, LSU, RPB2

\section{Introduction}

Surveys of species in the Entolomataceae Kotl. \& Pouzar were conducted during April-May of 2010-12 in the temperate rainforests of central New South Wales and February-March 2009-12 from various localities within the Wet Tropics Bioregion throughout northeastern Queensland. Among the 918 entolomatoid collections obtained during the surveys, species of Leptonia (Fr.) P. Kumm. are numerous. Here we describe three new species, L. boardinghousensis, L. ambigua, and L. omphalinoides and report L. poliopus and L. umbraphila new for Australia.

The generic concept of Leptonia remains uncertain, because phylogenetic analyses do not support monophyly for species included in the genus and the major sub-clades containing Leptonia spp. lack statistical support (CoDavid et al. 2009, Baroni \& Matheny 2011). Until resolution of the generic 
TABLE 1. Collection identifier and GenBank accession numbers of Leptonia species.

\begin{tabular}{|c|c|c|c|c|}
\hline \multirow{2}{*}{ Species } & \multirow{2}{*}{ Collection } & \multicolumn{3}{|c|}{ GENBANK ACCESSION NUMBERS } \\
\hline & & $\mathrm{mtSSU}$ & LSU & RPB2 \\
\hline \multirow[t]{4}{*}{ L. boardinghousensis } & Largent 9875 & - & JQ756410 & JQ756425 \\
\hline & Largent 9926 & JQ756397 & JQ756411 & JQ756426 \\
\hline & Largent 9935 & - & JQ756412 & JQ756427 \\
\hline & Largent 10086 & JQ756398 & JQ756413 & JQ756428 \\
\hline \multirow[t]{2}{*}{ L. ambigua } & Largent 9872 & JQ756399 & JQ756414 & JQ756429 \\
\hline & Largent 10130 & - & JQ756415 & JQ756430 \\
\hline \multirow[t]{2}{*}{ L. omphalinoides } & Largent 9673 & JQ756400 & JQ756416 & JQ756431 \\
\hline & Largent 9800 & JQ756401 & JQ756417 & JQ756432 \\
\hline \multirow[t]{3}{*}{ L. poliopus } & Largent 10209A & JQ756402 & JQ756418 & JQ756433 \\
\hline & Largent 10209B & JQ756403 & JQ756419 & JQ756434 \\
\hline & Largent 10209C & JQ756404 & JQ756420 & JQ756435 \\
\hline \multirow[t]{5}{*}{ L. umbraphila } & Largent 9629 & JQ756405 & - & JQ756436 \\
\hline & Largent 9630 & JQ756406 & JQ756421 & JQ756437 \\
\hline & Largent 9640 & JQ756407 & JQ756422 & JQ756438 \\
\hline & Largent 9766 & JQ756408 & JQ756423 & JQ756439 \\
\hline & Largent 9793 & JQ756409 & JQ756424 & JQ756440 \\
\hline
\end{tabular}

and phylogenetic concepts, we follow Largent (1994), who recognizes the following combination of morphological characters for Leptonia: a habit that is typically mycenoid, collybioid, omphalinoid, or (rarely) tricholomatoid; a pileus that is squamulose or tomentulose to tomentose at least on the disc; a convex, parabolic, broadly convex, or convex-depressed pileus shape; pileipellis typically composed of erect hyphae at least on the discs of young basidiomes; inflated pileocystidia averaging $>10 \mu \mathrm{m}$ in diameter; lipoid globules and oleiferous hyphae absent or (if present) not abundant; aborted basidia typically absent.

\section{Materials \& methods}

\section{Macromorphological and micromorphological features}

Colors of basidiomes were described subjectively and coded according to Kornerup \& Wanscher (1978: 196-225, Diagrams Section), with color plates noted in parentheses. In descriptions color plates are abbreviated to indicate the page number, column(s), and row(s) [e.g., 8D-F5-6 = page 8, columns D-F, rows 5-6.] Common color names are from the charts at the top of each page, with technical color names enclosed by quotation marks at the bottom of each page in the Color Names subsection [e.g., the common name for plate 1 , column A, row 2 is yellowish white, and the technical name is 'milk white'].

Measurements include: the arithmetic means $(x)$ of spore lengths and widths \pm one standard deviation in $\mathrm{N}$ objects measured; the quotient of spore length by width (E) indicated as a range variation in $\mathrm{N}$ objects measured and the mean of E-values (Q) 
\pm standard deviations. The sample size $(\mathrm{N})$ equals the total number of microscopic structures measured ( $\mathrm{x}$ ) and number of basidiomes studied (y) and follows the format $\mathrm{N}=\mathrm{x} / \mathrm{y}$. The following $\mathrm{Q}$ values define general basidiospore shape: isodiametric $-\mathrm{Q}=$ 1.0-1.15; subisodiametric-Q $=1.16-1.27$; heterodiametric- $\mathrm{Q}>1.27$ (Largent 1994).

The techniques and equipment for collecting data in the field, measuring basidiospores, and obtaining digital photographs of microscopic features follow Largent et al. (2011a).

All collections from New South Wales cited in the 'Additional collections examined' are deposited in The Plant Pathology Herbarium, Orange Agricultural Institute (DAR); Queensland collections were split, with duplicates deposited in the Australian Tropical Herbarium (CNS) and The Queensland Herbarium (BRI). All holotype and isotype collections are deposited in the herbaria designated using acronyms used in Thiers (2012).

\section{DNA sequences}

DNA extraction and Polymerase Chain Amplification (PCR) protocols for the mitochondrial small subunit of the ribosomal DNA (mtSSU), variable domains (D1, D2) of the nuclear large subunit (LSU), and the second largest subunit of the RNA polymerase gene (RPB2) follow Largent et al. (2011, 2013). For RPB2 amplification we used primers rpb2-i6f and rpb2-i7r (Co-David et al. 2009). Alternatively, we used additional forward RPB2 primers (rpb2-EntF1 and rpb2-EntF2; Largent et al. 2013) in combination with one of three reverse primers: rpb2-EntR1b (5' to $3^{\prime}-$ ATG GAT YTC RCA RTG TGT CCA), rpb2-EntR2 (5' to $3^{\prime}$ - GTG GAT TTC RCA RTG AGT CCA), or rpb2-EntR4 (5' to $3^{\prime}$ - TGA ATY TCR CAR TGC GTC CCA). Sequences were generated on an Applied Biosystems 3130xl Genetic Analyzer at Middle Tennessee State University using the sequencing and precipitation protocols outlined in Largent et al. (2011a,b). Accessions for sequences obtained from the three genes are provided in TABLE 1.

\section{Taxonomy}

Leptonia boardinghousensis Largent, sp. nov.

Plates 1-2

MycoBank MB 802806

Differs from Inocephalus quadratus by its basidiome colors, long rostrate-ventricose opaque hymenial cystidia, and heterodiametric 6-7(-8)-angled basidiospores.

Type - Australia, New South Wales, Watagans National Park, Boardinghouse Dam Track within $20 \mathrm{~m}$ of $32^{\circ} 59^{\prime} 57^{\prime \prime} \mathrm{S} 151^{\circ} 24^{\prime} 15^{\prime \prime} \mathrm{E}$, 12 April 2011, DL Largent 10086 (holotype, DAR).

EтумоLоgy - referring to Boardinghouse Dam Track in Watagans National Park.

PILEus 8-40 mm broad, 3-14 $\mathrm{mm}$ high, dull, always opaque (not translucent) and not hygrophanous; in young basidiomes convex to broadly convex then broadly parabolic, irregularly campanulate, plano-convex, and eventually uplifted, rarely obscurely umbonate in expanding and maturing basidiomes; at first entirely tomentulose or tomentulose-squamulose, in expanding basidioma remaining tomentulose to tomentulose-squamulose on or near the disc, squamulose towards the margin and appressed-fibrillose-striate at the margin, 
eventually in mature forms becoming appressed-fibrillose and then striate and rimose from the margin to near the disc; entirely orange (6A6) in young and protected basidiomes, in exposed basidiomes the tomentum, squamules, and fibrils at first dark brown with a reddish tone (7 or 8F6-7), becoming a bit lighter (7 or 8E5-7) and eventually fading to light brown (6-7C-D3-6); margin incurved to more typically decurved then uplifted, eventually wavy to lobed and split in mature forms; context reddish white to pale red (6-7A-B2-5) becoming more reddish in a rimose surface, $0.5-1.0 \mathrm{~mm}$ thick above the stipe, nearly nonexistent at the margin. ODOR weakly fungal, at times faintly pleasant or fragrant. TASTE slightly unpleasant or bitter and astringent. LAMELlaE 3-20 mm long, 1-7 mm deep, adnexed, close to subdistant and narrow to moderately broad at first, then subdistant and sigmoid, ventricose, or broad with maturity, at first pinkish white (6-7A2) darkening to brownish orange (5-7A3) and then pale red to pastel red (7A, B or C3-4) with basidiospore maturity; margin typically smooth and concolorous, in some lighter colored and faintly fimbriate. STIPE 25-72 mm long, $0.75-5.0 \mathrm{~mm}$ broad at apex, middle, and base, in some flattened and longitudinally grooved and then at the apex 5-6 $\times 2 \mathrm{~mm}$ at the apex, $4 \times 2$ or $5 \times 4 \mathrm{~mm}$ broad in the middle, and $3 \times 2.5$ or $5 \times 4 \mathrm{~mm}$ broad at base, equal to often tapered with the apex smaller or in one with the base smaller, pruinose at the apex, smooth to the eye but weakly longitudinally striate under $10 \times$, at first pale orange to pale red (5-7A3-4), remaining so at the apex, but darkening (5-7A-B3-5) with maturity; hollow, typically sturdy and stiff, rarely fragile and splitting longitudinally; basal tomentum white, typically at first scarce, often remaining so with age but at times becoming moderate to abundant in basidiomes in deep humus, rarely absent and then only in exposed basidiomes found in shallow or compacted humus along trails. BRUISING REACTIONS stipe browning when handled.

BASIDIOSPORES in profile view 6-7(-8)-angled, angles somewhat knobby, subheterodiametric to heterodiametric, in end view 6-angled and isodiametric, 8.1-11.7 × 6.0-8.9 $\mu \mathrm{m}(x=9.7 \pm 0.7 \times 7.2 \pm 0.53 \mu \mathrm{m} ; \mathrm{E}=1.13-1.62 ; \mathrm{Q}=1.36$ \pm 0.10 (heterodiametric); $\mathrm{N}=112 / 4)$. BAsIDIA clavate, 4-sterigmate, in some with fairly large granules, $32.1-43.5 \times 6.4-11.2 \mu \mathrm{m}(x=38.6 \pm 3.9 \times 9.6 \pm 1.6$ $\mu \mathrm{m} ; \mathrm{E}=3.5-5.2 ; \mathrm{Q}=4.1 \pm 0.60 ; \mathrm{N}=13 / 2)$. CheIlocystidia versiform, clavate, obclavate, clavate and acuminate, ventricose-rostrate, or ventricose-rostrate with the rostrum strangulated and tapered, thin-walled to slightly thick-walled, colorless, scattered to abundant, 51.3-111.4 × 10.1-32.1 $\mu \mathrm{m}(\mathrm{E}=3.16-6.30$; $\mathrm{Q}=4.2 \pm 0.77 ; \mathrm{N}=15 / 2$ ). Pleurocystidia as pseudocystidia, similar in shape but typically longer than the cheilocystidia, often originating from the outer portions of the lamellar trama, not associated with the oleiferous hyphae, opaque but colorless, 81.3-147.6 × 12.5-18.5 $\mu \mathrm{m}(\mathrm{E}=3.6-7.6$; $\mathrm{Q}=5.5 \pm 1.4$; $\mathrm{N}=11 / 2$ ). Lamellar tramal hyphaE subparallel, rather long and broad, 


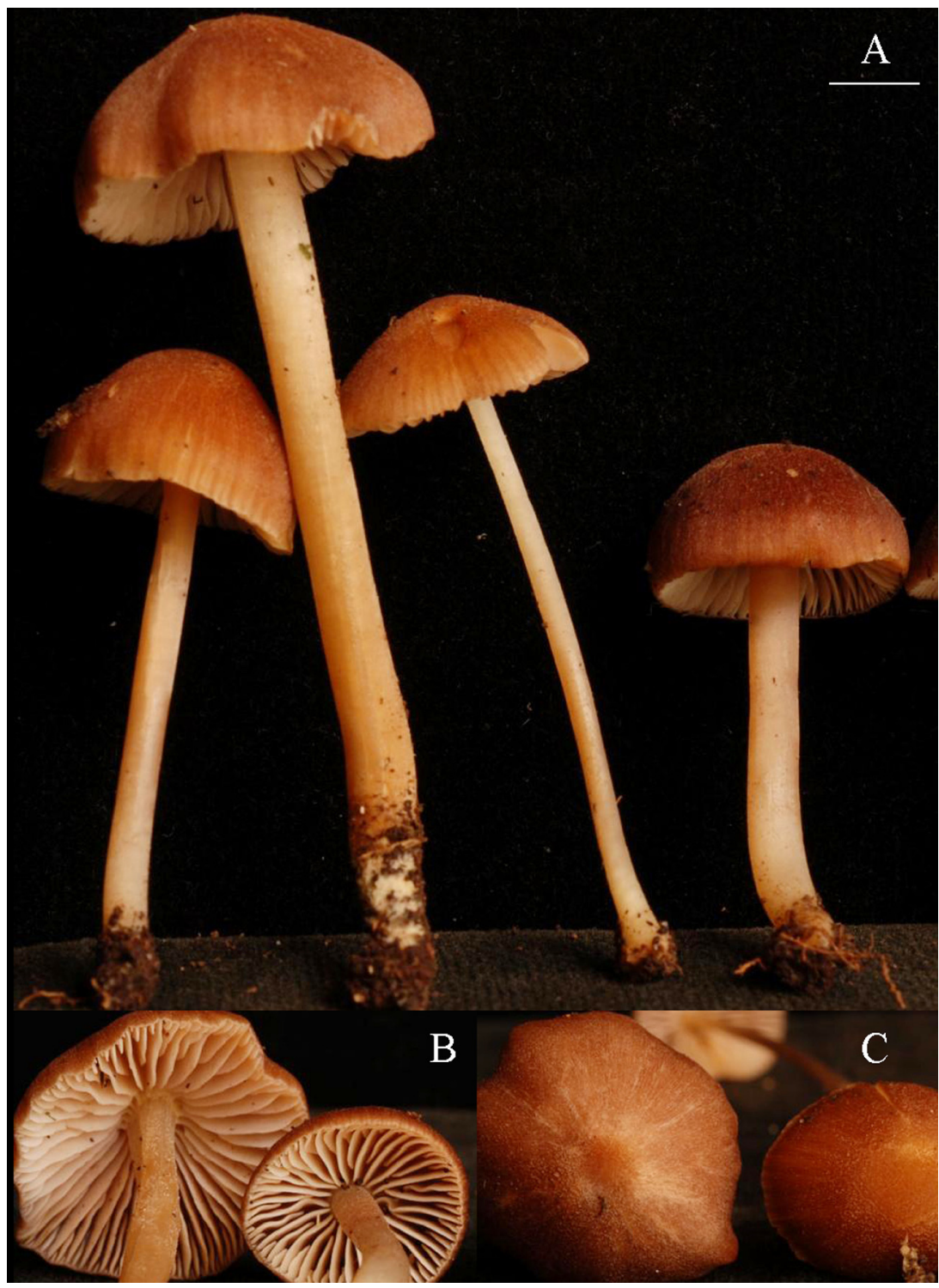

Plate 1. Leptonia boardinghousensis \{DLL 10086 holotype\}. A: Basidiomata habit; B: Lamellar attachment (note whitish edges on maturing lamellae and pruinose stipe apex); C: Pileus surface, mature surface tomentulose to tomentulose-squamulose on the disc, appressed fibrillose elsewhere (left), immature surface, entirely tomentulose (right). Bar (A-C) $=10 \mathrm{~mm}$. 
without lipoid globules, 49.1-305.2 × 3.7-32.2 $\mu \mathrm{m}(\mathrm{N}=14 / 2)$. Pileipellis a layer of entangled hyphae, in young basidiomes more or less erect, in older basidiomes erect to suberect in the center of pileus and semi-erect towards the margin, and repent at the margin. PiLeocystidia cylindro-clavate to clavate to broadly clavate, $27.8-180.6 \times 6.0-19.8 \mu \mathrm{m}(\mathrm{E}=2.0-13.5 ; \mathrm{Q}=6.6 \pm 3.8 ; \mathrm{N}=18 / 3)$. Pileal tramal hyphae entangled, similar in size and shape to the lamellar trama. STIPITIPELLis with rare to scattered clusters of hymenial elements at the apex, a cutis elsewhere. CAulocystidia absent. Oleiferous hypHAE rare, scattered, or absent in the pileal and lamellar trama. Lipoid GLOBULES absent. Brilliant granules absent. Pigmentation in the pileipellis cytoplasmic as well as faintly externally incrusted on the outer hyphal walls. Clamp CONNECTIONS absent in all tissues.

ECOLOGY \& DISTRIBUTION - Rarely solitary, more often scattered, gregarious, or even caespitose in soil amongst leaf litter, in wet sclerophyll, warm temperate gallery rainforest; central or northern Hunter District, New South Wales, April-May.

\begin{abstract}
Additional collections examined - AUSTRAlia. New South Wales, central Hunter District, Barrington Tops National Park, Williams River Day Use Area, end of Blue Gum Track, $32^{\circ} 09^{\prime} 03.4^{\prime \prime} \mathrm{S} 151^{\circ} 31^{\prime} 35.1^{\prime \prime} \mathrm{E}, 14$ April 2010, DL Largent 9875; 32 $09^{\prime} 08^{\prime} .3^{\prime \prime} \mathrm{S}$ $151^{\circ} 31^{\prime} 37.0^{\prime \prime} \mathrm{E}$, DL Largent 9877; 32 $09^{\prime} 03.2^{\prime \prime} \mathrm{S} 151^{\circ} 31^{\prime} 23.6^{\prime \prime} \mathrm{E}, 18$ April 2010, DL Largent 9894; 32 09'03.2"S $151^{\circ} 31^{\prime} 23.6^{\prime \prime} \mathrm{E}, 4$ May 2011, DL Largent 10193. Williams River Day Use Area, Track to Pool of Reflections, $32^{\circ} 08^{\prime} 15.8^{\prime \prime} \mathrm{S} 151^{\circ} 30^{\prime} 38.2^{\prime \prime} \mathrm{E}, 22$ April 2010, DL

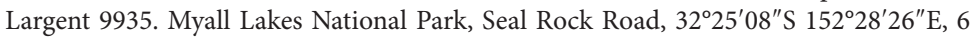
May 2011, DL Largent 10203. Watagans National Park, Boardinghouse Dam Track, $32^{\circ} 59^{\prime} 57.7^{\prime \prime} \mathrm{S} 151^{\circ} 24^{\prime} 15.9^{\prime \prime} \mathrm{E}, 13$ April 2010, DL Largent 9867; $32^{\circ} 59^{\prime} 57.8^{\prime \prime} \mathrm{S} 151^{\circ} 24^{\prime} 15.4^{\prime \prime} \mathrm{E}$, 21 April 2010, DL Largent 9926; 32 $59^{\prime} 57.7^{\prime \prime S} 151^{\circ} 24^{\prime} 15.8^{\prime \prime} \mathrm{E}, 28$ April 2010, DL Largent 9958; $32^{\circ} 59^{\prime} 58.2^{\prime \prime} \mathrm{S} 151^{\circ} 24^{\prime} 15.4^{\prime \prime} \mathrm{E}$, DL Largent 9959; 32 $59^{\prime} 59^{\prime} .2^{\prime \prime} \mathrm{S} 151^{\circ} 24^{\prime} 16.3^{\prime \prime} \mathrm{E}, \mathrm{DL}$

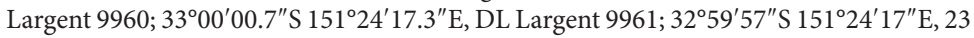
April 2011, DL Largent 10144, 10145; 32 $59^{\prime} 57^{\prime \prime S} 151^{\circ} 24^{\prime} 17^{\prime \prime E}, 1$ May 2011, DL Largent 10175.
\end{abstract}

Distinctive Characters - The basidiome color changes of orange then pinkish to reddish in the stipe, orange then dark brown with a reddish tone in the pileus, pinkish white in the lamellae, and reddish white to pale red in the pileal context; an entirely tomentulose pileal surface at first that becomes striate to the margin with maturity; basidiospores $6-7$-angled and averaging $<10 \mu \mathrm{m}$ $x<7.5 \mu \mathrm{m}$; versiform hymenial cystidia; and clampless hyphae.

Comments - In 2010 and 2011, several L. boardinghousensis populations of 10-20 basidiomes each were common throughout the Boardinghouse Dam

PLATE 2. Leptonia boardinghousensis \{DLL 9925 A-B, D; DLL 9867 C,E\}. A: Basidiospores; B: Faintly incrusted pigment on hyphae of pileipellis; C: Pileipellis and pileocystidia near pileal margin; D: Cheilocystidia, pleurocystidia, and oleiferous hyphae in lamellar trama; E: Ventricose-rostrate pleurocystidia with rostrum strangulated and tapered, basidia with sterigma, basidioles in squash mount. Bars: $\mathrm{A}=5 \mu \mathrm{m} ; \mathrm{B}=25 \mu \mathrm{m} ; \mathrm{C}=25 \mu \mathrm{m} ; \mathrm{D}=40 \mu \mathrm{m} ; \mathrm{E}=25 \mu \mathrm{m}$. 
Leptonia spp. \& comb. nov. (Australia) ... 17

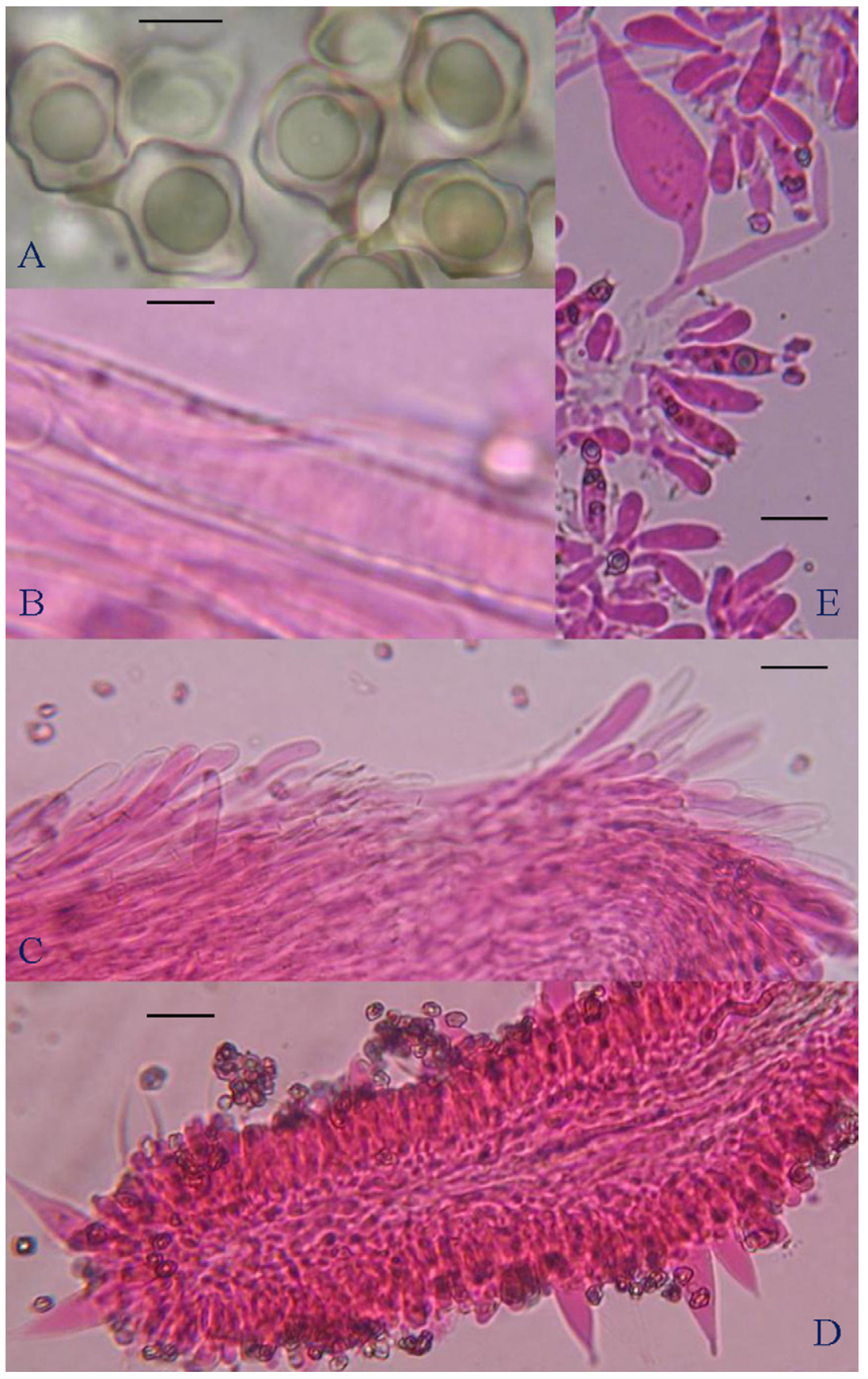


Track in Watagans National Park. Collections found in relatively deep humus and protected by a dense overstory regularly consisted of large basidiomes with pilei up to $40 \mathrm{~mm}$ broad and stipes $35-75 \mathrm{~mm}$ long and with orange colors dominant. Collections in more open areas with less humus consistently produced smaller pilei ( $<28 \mathrm{~mm}$ broad) and shorter stipes $(25-55 \mathrm{~mm}$ long) with brown to reddish brown color predominating.

The pantropical Inocephalus quadratus (Berk. \& M.A. Curtis) T.J. Baroni resembles L. boardinghousensis macroscopically but differs microscopically in its cuboidal basidiospores and cylindro-clavate to clavate cheilocystidia (Baroni \& Halling 2000, Noordeloos \& Hausknecht 2007).

Leptonia ambigua Largent, sp. nov.

Plates 3-4

MrcoBank MB 802807

Differs from Leptonia tjallingiorum by smaller basidiomes, the dark greyish violet to blackish blue pileus, the subisodiametric basidiospores, and the absence of cheilocystidia and clamp connections in the pileipellis.

Type - Australia, New South Wales, Barrington Tops National Park, end of Blue Gum Track, within $20 \mathrm{~m}$ of $32^{\circ} 09^{\prime} 03.8^{\prime \prime} \mathrm{S} 151^{\circ} 31^{\prime} 30.2^{\prime \prime} \mathrm{E}, 21$ April 2011, DL Largent 10130 (holotype, DAR).

ЕтумOLOGY - derived from the Latin ambiguus (= ambiguous), referring to the obscure angles at the apex of some basidiospores.

Pileus 8-33 mm broad, 5-10 $\mathrm{mm}$ high; opaque and not translucent, not hygrophanous; typically plane, at times obscurely umbonate, never depressed; when young convex to parabolic, upon expansion and maturity becoming broadly convex and eventually plane; at first entirely densely matted fibrillose to matted tomentulose then remaining matted tomentulose in the center and becoming appressed squamulose elsewhere, and eventually appressed fibrillose at or near the margin, not striate; at first entirely dull violet to near dark violet to between dark greyish violet and blackish blue (18E4 or 19E-F3-4), remaining so on the disc but the squamules and fibrils fade to greyish lilac (16D2) or purplish grey (14-15C2), eventually the violaceous color fades completely and the pileus becomes brown (6-7D-F3-4); context pallid, $1 \mathrm{~mm}$ thick above the stipe, nearly non-existent at the margin; margin decurved then plane. ODOR indistinct. Taste indistinct, mild. Lamellae 5-13 mm long, 1-5 mm deep, adnexed or narrowly adnate at all times, close then subdistant, narrow then moderately broad, at first violet white (18A2), quickly becoming reddish grey (7A2), then white to orange white (5-7A1-2), and eventually pale brownish orange (6C4) with basidiospore maturity; margin smooth and concolorous. STIPE 22-54 mm long, apex 1-3 $\mathrm{mm}$ broad, base 1-4 $\mathrm{mm}$ broad, equal to slightly enlarged towards the base, longitudinally appressed fibrillose except for the pruinose apex, at first the fibrils dull violet (18E4, 18D3-4) then violet grey (16D2 or 16B2) and eventually dull red (9B3) or reddish grey (9C2); 


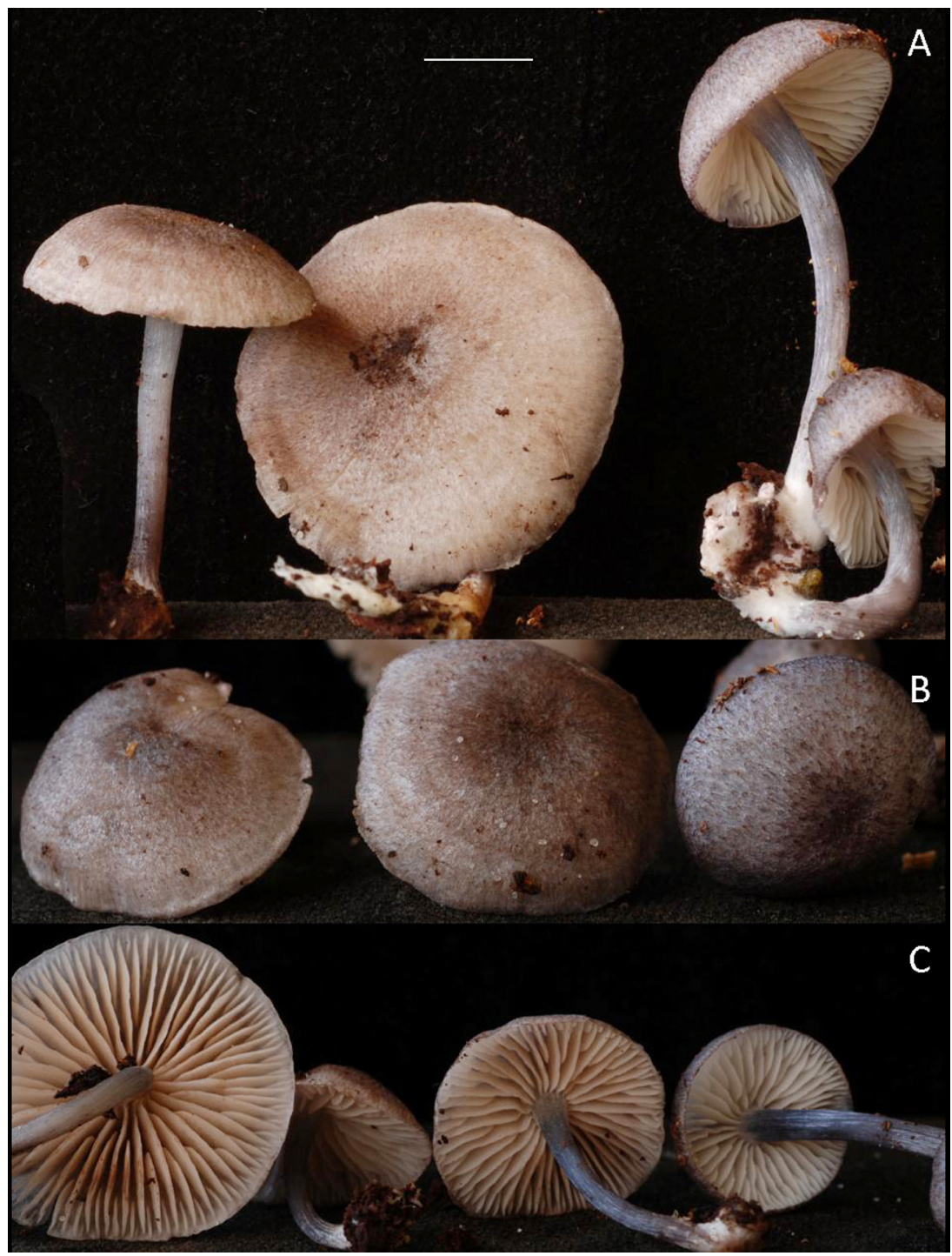

PLATE 3. Leptonia ambigua \{DLL 10130 holotype\}. A: Basidiomata stature, mature (left), young (right); B: Pileus surface, young (right), maturing (to the left); C: Lamellae and stipe color; young (right), mature (far left). Bar (A-C) $=10 \mathrm{~mm}$.

hollow and somewhat stiff; basal tomentum moderate to scarce, white at first, then yellowish. Bruising Reactions pileus, lamellae, and stipe none; basal tomentum at time becoming orangish. 
BASIDIOSPORES isodiametric to heterodiametric, in profile and dorsiventral views, 5-angled, all angles usually distinct but at times distinctly angular on the basal end and obscurely angular or rounded at the apex, isodiametric and 5-6-angled in polar view, $6.2-8.3 \times 5.2-7.5 \mu \mathrm{m}(x=7.5 \pm 0.4 \times 6.3 \pm 0.5 \mu \mathrm{m}$; $\mathrm{E}=1.04-1.40 ; \mathrm{Q}=1.19 \pm 0.09$ (subisodiametric); $\mathrm{N}=59 / 2$ ). BAsIdiA clavate, hardly tapered at the base, full of granules just before spore production, $27.1-40.0 \times 7.1-11.8 \mu \mathrm{m}(x=33.2 \pm 3.4 \times 9.3 \pm 1.2 \mu \mathrm{m} ; \mathrm{E}=3.11-4.56 ; \mathrm{Q}=3.59$ $\pm 0.34 ; \mathrm{N}=18 / 2)$; 4-sterigmate with the sterigma up to $8.0 \mu \mathrm{m}$ long. HymeNial Cystidia absent. LAMELlar TRAMAL HyPhAE subparallel, in the center of the lamella mostly short to moderately long, a few long in the center of the lamellae, hyphae with rounded ends, 41.4-320.0 × 7.8-22.2 ( $\mathrm{N}=16 / 2)$. Pileipellis an entangled layer of hyphae composed of \pm moniliform chains of 3-4 cells, the chains entangled, more or less erect on the disc, suberect and in clusters elsewhere with a cutis between the clusters, up to $400 \mu \mathrm{m}$ thick on the disc, $205 \mu \mathrm{m}$ near the disc. Pileocystidia present as the terminal cells of a chain of cells, consistently broad, clavate to cylindro-clavate, 33.7-111.7 $\times 9.8-21.3 \mu \mathrm{m}$ $(x=15.0 \pm 3.2 \mu$ wide; $\mathrm{E}=2.55-6.80 ; \mathrm{Q}=4.13 \pm 1.32 ; \mathrm{N}=16 / 2)$. Pileal tramal HYPHAE similar in shape but shorter and broader than the lamellar trama, 57.5-155.4 × 9.8-22.2 $\mu \mathrm{m}(\mathrm{N}=7 / 1)$. STIPITIPELLIS a layer of hyphae similar in structure to pileipellis everywhere except at the apex where there are clusters of colorless caulocystidia with a few basidia present. CAulocystidia at the apex, colorless, in clusters, pyriform to broadly clavate to broadly cylindro-clavate 23.9-108.1 × 8.5-20.2 $\mu \mathrm{m}(\mathrm{E}=1.81-12.73) ; \mathrm{N}=16 / 2)$; elsewhere cylindroclavate to clavate, similar in size, shape, and pigmentation as the pileocystidia. Oleiferous hyphae absent. Lipoid globules absent. Brilliant granules scattered. Pigmentation cytoplasmic and intracellular, brownish and insoluble in $3 \% \mathrm{KOH}$ in the pileo- and caulocystidia; faintly parietal or incrusting in the lower portion of the pileipellis. CLAMP CONNECTIONS present at the base of the basidia; absent in all other tissues.

ECOLOGY \& DISTRIBUTION - Typically gregarious, rarely scattered but rarely caespitose, on decomposing logs and in mosses in a subtropical gallery rainforest, Barrington Tops National Park, New South Wales. In April 2009 and 2010 several different populations were common on decaying logs in various localities towards the end of the Blue Gum Track in the Williams Day Use Area. Each population produced approximately 50-100 basidiomes typically in acrocarpous mosses resembling a species of Dicranum Hedw.

Additional collections examined - AUSTRAlia. New South Wales, central Hunter District, Barrington Tops National Park, Williams River Day Use Area, end of Blue Gum Track, 3209'03.2"S 151 31'28.6"E, 8 April 2010, DL Largent 9847; $32^{\circ} 09^{\prime} 10.7^{\prime \prime} \mathrm{S} 151^{\circ} 31^{\prime} 38.3^{\prime \prime} \mathrm{E}, 14$ April 2010, DL Largent 9872, 9881; 32 09'04.7"S $151^{\circ} 31^{\prime} 34.1^{\prime \prime} \mathrm{E}, 18$ April 2010, DL Largent 9899; 3209'05.0"S 151³1'30.6"E, 20 April 2010, DL Largent 9914. 


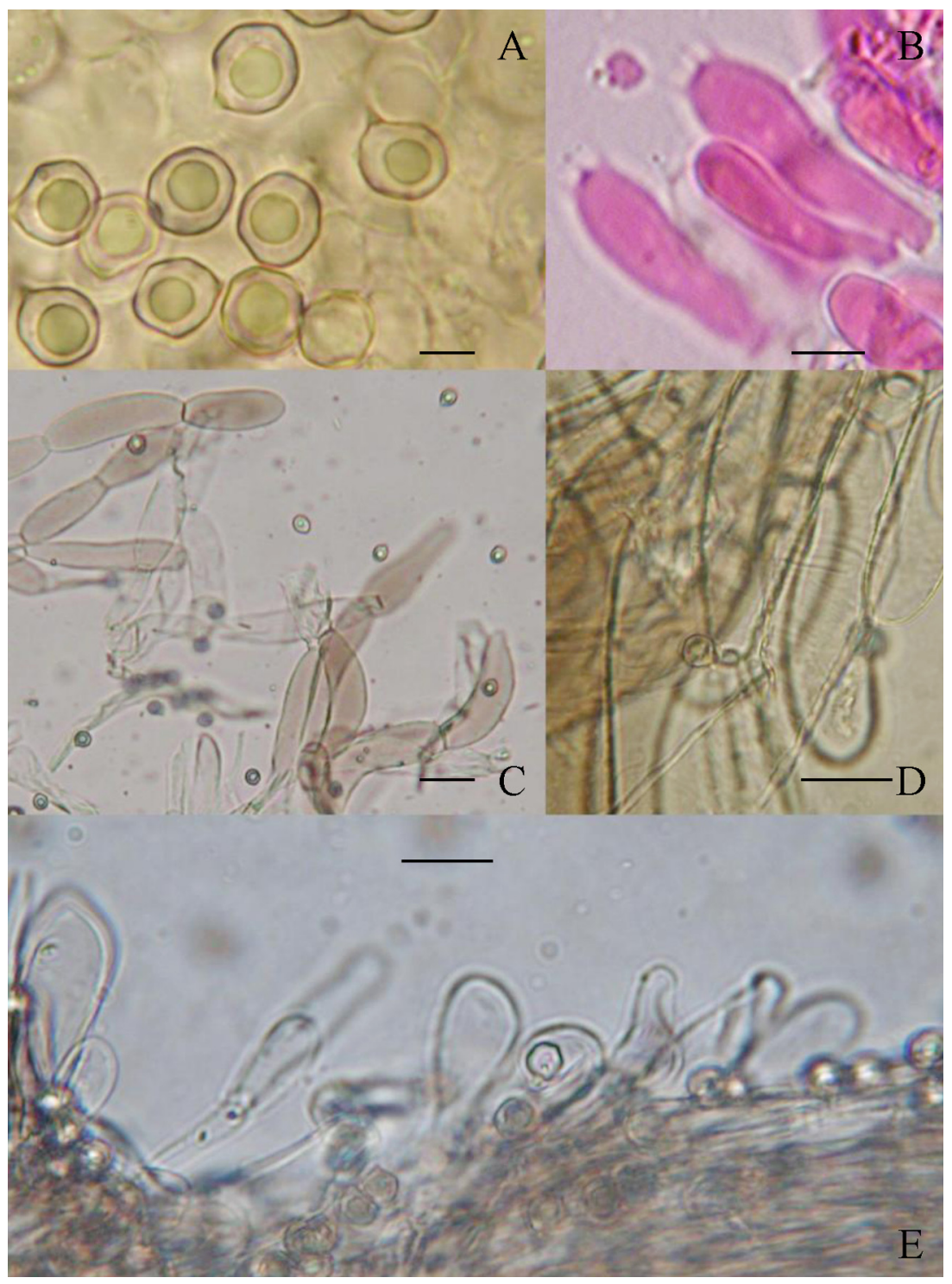

Plate 4. Leptonia ambigua \{DLL 10130 holotype C-E; DLL 9872 A-B $\}$. A: Basidiospores; B: Basidia and basidioles; C: Pileipellis and terminal pileocystidia with uniform brownish cytoplasmic pigment in $3 \% \mathrm{KOH}$; D: Parietal pigmentation in pileipellis; E: Stipitipellis at stipe apex with pyriform caulocystidia; F: Stipitipellis at stipe apex with clavate cheilocystidia. Bars: $\mathrm{A}=5 \mu \mathrm{m}$; $\mathrm{B}=10 \mu \mathrm{m} ; \mathrm{C}-\mathrm{D}=15 \mu \mathrm{m} ; \mathrm{E}=10 \mu \mathrm{m}$. 
Distinctive Characters - Habitat on decomposing logs covered with mosses; convex dark greyish violet pileus that becomes brown with maturity; violet-white lamellae at first; dull violet stipe that becomes grayish violet with age; subisodiametric basidiospores, distinctly angular except at times obscurely angular at the apex; two types of caulocystidia at the stipe apex; the broad tramal hyphae in the lamellae; and no clamp connections in the pileipellis.

Comments - Its basidiome colors and stature, pileipellis type, and brownish cytoplasmic pigment cause L. ambigua to resemble several lignicolous species in Leptonia subg. Leptonia.

Entoloma obtusisporum E. Horak from Brazil also has obtusely angular basidiospores and lacks cheilocystidia but differs from L. ambigua by its white smooth stipe, lack of parietal pigmentation, and slightly smaller, isodiametric basidiospores that are 5.5-7.0 $\mu \mathrm{m}$ in all dimensions (Horak 1982). Rhodophyllus dichrooides Romagn. \& Gilles from Gabon (Romagnesi \& Gilles 1979), the European L. dichroa (Pers.) P.D. Orton (Noordeloos 1992), and L. euchroa (Pers.) P. Kumm. from Europe and Australia (Noordeloos 1992, May \& Wood 1997) are differentiated by their heterodiametric angular basidiospores and abundant clamp connections in the pileipellis. Leptonia tjallingiorum (Noordel.) P.D. Orton from Europe is differentiated from L. ambigua by larger tricholomatoid basidiomes, abundant cheilocystidia, heterodiametric basidiospores, abundant clamp connections, and the absence of blue-black or dark violet colors in the pileus (Noordeloos 1992, 2004).

Leptonia omphalinoides Largent, sp. nov.

Plates 5-6

MycoBank MB 802808

Distinct in the Entolomataceae by the lignicolous omphalinoid small basidiomes, small quadrate or cuboidal basidiospores, and clampless hyphae.

TYPE - Australia, northern Queensland, Mossman National Park, lower Track just past observation platform, within $20 \mathrm{~m}$ of $16^{\circ} 28^{\prime} 17.6^{\prime \prime} \mathrm{S} 145^{\circ} 19^{\prime} 51.7^{\prime \prime} \mathrm{E}, 18$ March 2010, DL Largent 9800 (holotype, BRI; isotype, CNs).

EтумоLOGY - from the Greek ending “-oides” referring to the omphalinoid basidiome stature.

Pileus 6-11 mm broad, 2-4 mm high; opaque, not hygrophanous; convex to broadly convex, umbilicate; minutely tomentulose to scabrous and punctate on disc, minutely squamulose with the squamules erect towards the margin, appressed-fibrillose on the margin, striate to the disc, dull; disc reddish brown (8F4 to $8 \mathrm{~F} 7$ 'mahogany brown'), elsewhere reddish brown but a little lighter than the disc (8-9E-F6-7), eventually remaining dark brown on the disc but fading to greyish brown with a reddish tint elsewhere (8E-F3-4; margin decurved, minutely hairy then crenulate; context dark and less than $0.5 \mathrm{~mm}$ thick above the stipe. Odor indistinct. Taste indistinct. Lamellae up to 


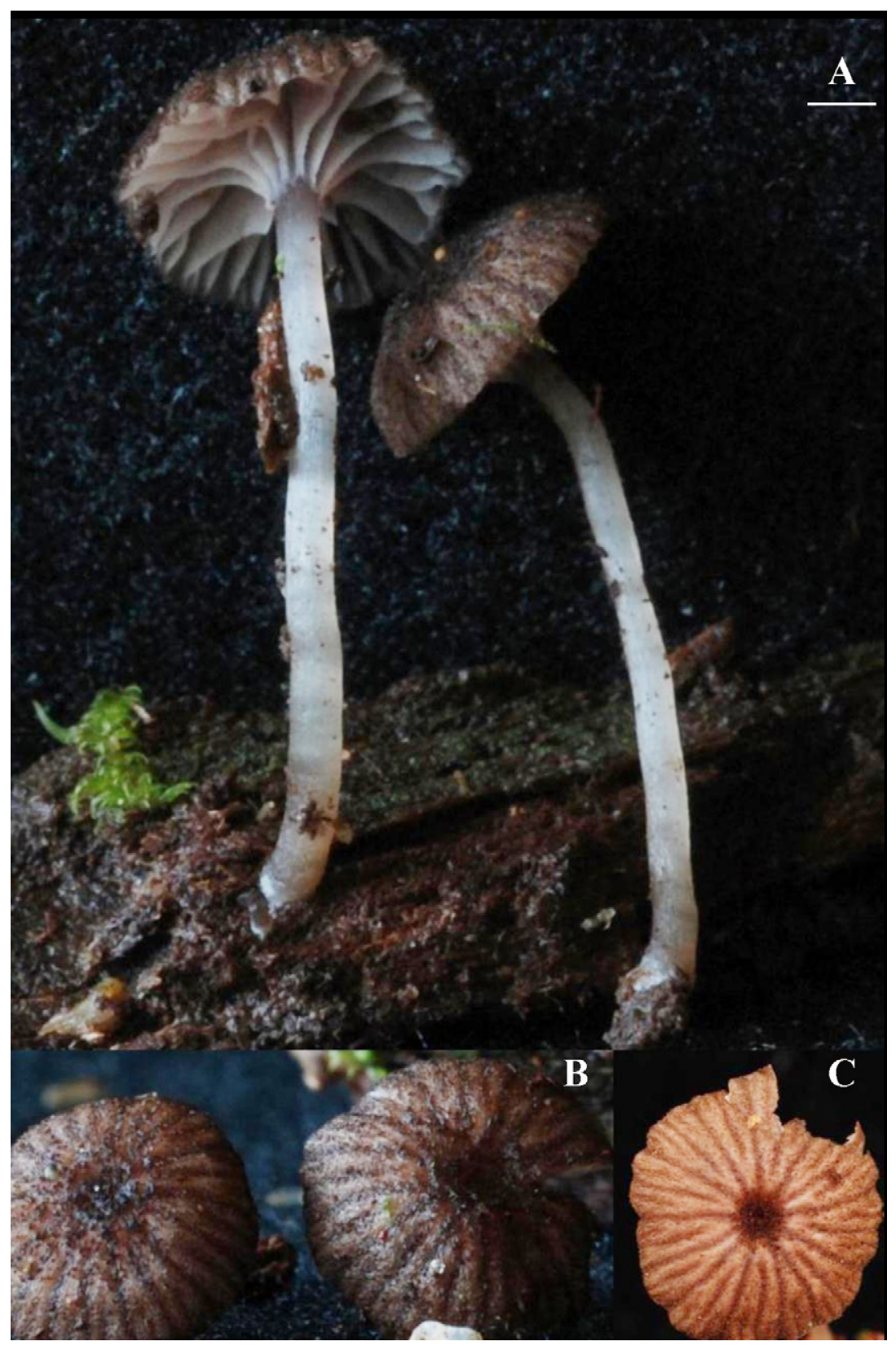

Plate 5. Leptonia omphalinoides \{DLL9800 holotype A,B; DLL 9373 C\}. A: Basidiomata stature; B: Pileal surface of young, dark basidiome; C: Pileal surface light form mature. Bar $(A-C)=2 \mathrm{~mm}$. 
12 per basidiome, 4-5 $\mathrm{mm}$ long, 1-1.5 $\mathrm{mm}$ deep, pallid greyish to off white when young, subdecurrent to decurrent, narrow, subdistant to distant; margin smooth and concolorous; lamellulae 1 to 3 between lamellae, in 1-2 tiers, 1 short or 2 short and 1 medium. STIPE 9-17 mm long, <1 mm broad, equal, glabrous, reddish grey to light dull red (8-9A1-2 or 8-9C2-3), hollow and very fragile; basal tomentum absent. BRUISING REACTIONs none.

BASIDIOSPORES consistently 4-angled, quadrate and small in all views, rarely cuboid, angles distinct and at times somewhat elongated and suggestively prismatic, isodiametric in polar views, subisodiametric to heterodiametric in profile and basal views, 4.6-8.4 $\times 3.7-6.7 \mu \mathrm{m}(x=6.1 \pm 0.9 \times 5.2 \pm 0.7 \mu \mathrm{m} ; \mathrm{E}=$ $1.00-1.52 ; \mathrm{Q}=1.19 \pm 0.12$ (subisodiametric); $\mathrm{N}=54 / 2$ ). BAsidia clavate to subclavate, $21.5-34.8 \times 7.2-11.3 \mu \mathrm{m}(x=28.4 \pm 3.7 \times 9.4 \pm 1.0 \mu \mathrm{m} ; \mathrm{E}=2.2-4.1$; $\mathrm{Q}=3.09 \pm 0.50 ; \mathrm{N}=24 / 2)$; base 3.1-5.1 $\mu \mathrm{m}$; 4-sterigmate, sterigma 2.4-3.6 $\mu \mathrm{m}$ long. Cheilocystidia and Pleurocystidia abundant, particularly on the decurrent portion of the lamellae, and morphologically similar, colorless, versiform (cylindric, acicular, narrowly to broadly rostrate-ventricose), 27.3-49.1 × 4.3-13.0 $\mu \mathrm{m}(x=41.0 \pm 4.9 \times 8.4 \pm 2.2 \mu \mathrm{m} ; \mathrm{E}=5.20-10.19$; $\mathrm{Q}=5.20 \pm 1.75 ; \mathrm{N}=21 / 2)$. LAMELLAR TRAMAL HYPHAE relatively small, 37.6-88.1 ×2.4-14.1 $\mu \mathrm{m}(\mathrm{N}=12 / 2)$. PILEIPELLIS 80-119 $\mu \mathrm{m}$ thick, badissima-type with laterally agglutinated, entangled hyphae but without collapsed cylindroclavate cells, composed of only 1-3 cells; Pileocystidia broadly clavate to broadly cylindro-clavate, on the disc $14.3-96.3 \times 4.0-23.1 \mu \mathrm{m}(x=56.5 \pm 14.3 \times$ $14.5 \pm 4.0 \mu \mathrm{m} ; \mathrm{E}=1.2-6.8 ; \mathrm{N}=16 / 2)$, away from the disc $29.5-135.5 \times 6.1-24.5$ $\mu \mathrm{m}(x=76.7 \pm 29.5 \times 17.2 \pm 6.1 \mu \mathrm{m} ; \mathrm{E}=2.5-10.6 ; \mathrm{N}=11 / 1)$. Pileal tramal HYPHAE small, not very long, and so thin as to appear non-existent in sections, 50.3-63.7 $\times 9.5-11.9 \mu \mathrm{m} ; \mathrm{N}=3 / 1$ ). STIPITIPELLIS with hymenial elements at or next to decurrent lamellae, and otherwise a cutis. CAULOCYSTIDIA absent. STIPE TRAMAL HYPHAE relatively small, 47.7-116.1 $\times 6.04-15.4 \mu \mathrm{m}(\mathrm{N}=9 / 2)$. Oleiferous hyPhAE rare in the trama. Lipoid globules absent. BRILliant granules abundant in the basidia. Pigmentation very dark brown and in large granules to plaque-like areas in the pileipellis, suggestively parietal in pileal trama. Clamp connections absent in all tissues.

ECOlOgY \& Distribution - Scattered on a single large decaying log, at the end of Marrdja Walk about 100 yards from the parking lot, Tribulation Section, Daintree National Park, and on piece of wood at base of a boulder on a ridge above an observational platform, lower river trail, Mossman National Park; mid-March.

Additional collections examined - AUSTRALIA. Queensland, Cook Region, Daintree National Park, Tribulation Section, $16^{\circ} 08^{\prime} 18.5^{\prime \prime}$ S $145^{\circ} 26^{\prime} 26.0^{\prime \prime}$ E, 20 March 2009, DL Largent 9673.

Distinctive characters - Small lignicolous omphalinoid basidiomes; striate pileus; badissima-type pileipellis lacking collapsed cylindro-clavate 


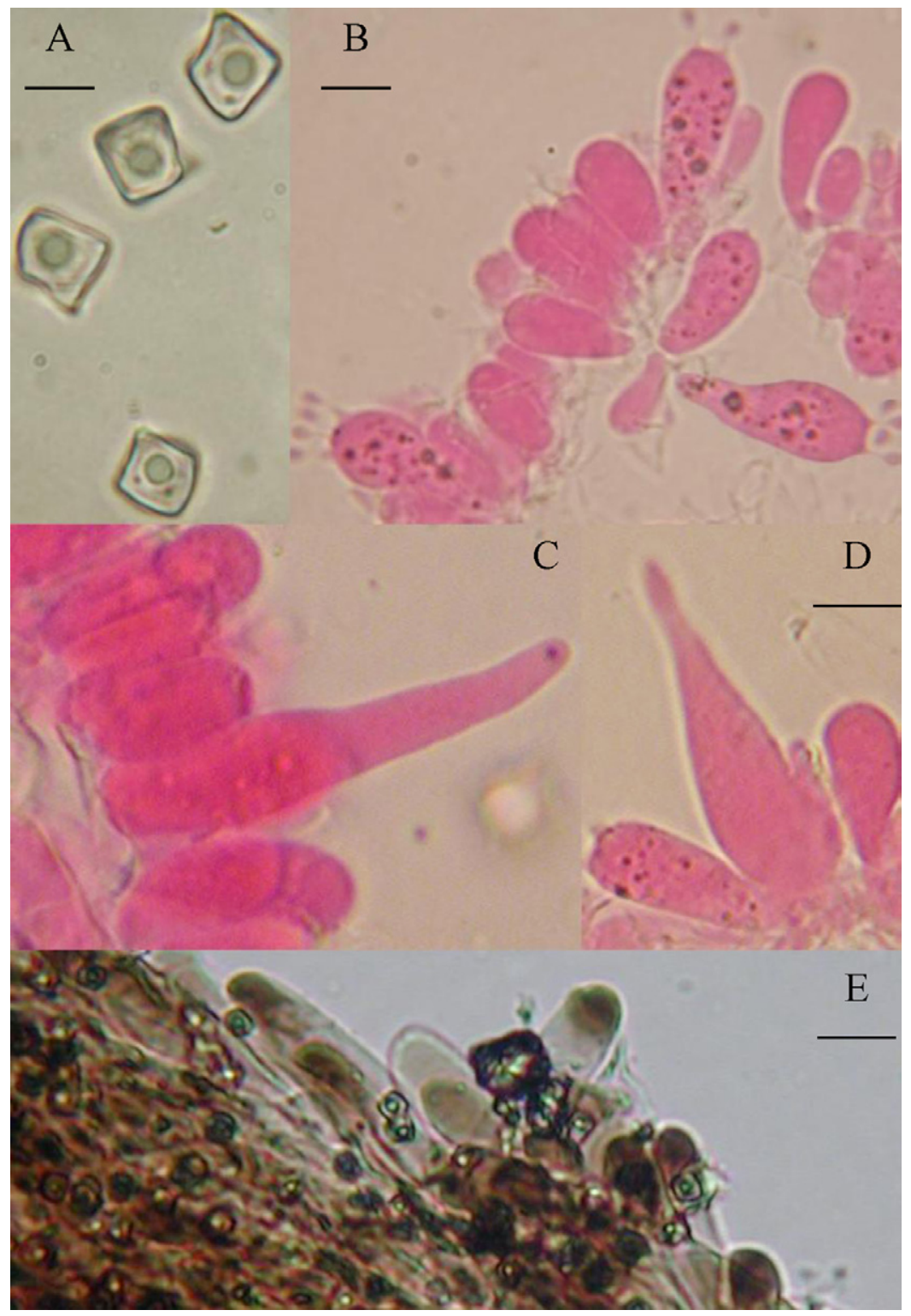

Plate 6. Leptonia omphalinoides \{DLL 9800 holotype E; DLL 9673 A - D\}. A: Basidiospores; B: Basidia with globules; C: Obclavate cystidium; D: Basidium, cystidium becoming rostrateventricose, vesiculate cystidium; E: Pileipellis near disc, cylindro-clavate, clavate to broadly cylindro-clavate pileocystidia with dark brown cytoplasmic pigment in plaque-like areas. Bars: $\mathrm{A}=6 \mu \mathrm{m} ; \mathrm{B}-\mathrm{D}=10 \mu \mathrm{m} ; \mathrm{E}=20.0 \mu \mathrm{m}$. 
pileocystidia; versiform hymenial cystidia; small 4-sterigmate basidia; dark brown plaque-like pigment in the pileipellis and suggestively parietal in the pileal trama; clampless hyphae; 4-sided subisodiametric basidiospores averaging $<6.5 \mu \mathrm{m} \times<5.5 \mu \mathrm{m}$.

Comments - Eccilia cubensis Murrill from Cuba and Entoloma brunneostriatum Dennis from Trinidad also have small, omphalinoid basidiomes and small basidiospores. Eccilia cubensis differs from L. omphalinoides by its octahedral, larger basidiospores (7-9 $\mu \mathrm{m})$, innately scaly pileus lacking striations, and slightly granular floccose stipe (Murrill 1911), while Entoloma brunneostriatum differs in its larger $(7-8 \times 6-8 \mu \mathrm{m})$ basidiospores, lack of hymenial cystidia, and smooth pileus and stipe (Dennis 1953).

Leptonia poliopus (Romagn.) P.D. Orton, Mycologist 5: 134 (1991).

Plates 7-8

三Entoloma poliopus (Romagn.) Noordel., Persoonia 10: 262 (1979).

PIleus 9-22 mm broad, 1-2 mm high, dull; striate to the disc, suggestively translucent; depressed, convex then broadly convex; when young entirely tomentulose, with expansion and maturity remaining tomentulose on the disc but forming squamules from the disc to the margin, eventually appressedfibrillose to nearly glabrous at or near the margin; at first greyish brown (6F3, 'negro') on the disc to a bit lighter brown elsewhere (6F3-4, between 'negro' and 'chocolate brown'), upon expansion retaining the greyish brown (6F3) color in the disc and in the striations but becoming dark brown (6F6, 'burnt umber' or 'vandyke brown') from near the center to the margin as the context shows through the areas between the squamules and the fibrils, hygrophanous between the marginal area and the center and thus becoming brownish orange to orange white (5 or 6C3 to 5-6A-B2-3); margin incurved to decurved then decurved, plane, and finally uplifted, even; context $<1 \mathrm{~mm}$ deep, concolorous with the surface. ODOR typically mild and indistinct, at times faintly fragrant. TASTE typically mild to nearly bitter. LAMELlae 4-10 mm long, 2-3 mm deep, broadly adnexed to adnate with a faint decurrent tooth or faintly subdecurrent, subdistant, moderately broad, pallid or off-white at first (5-6A2); margin in young and moderately aged basidiomes, smooth to the eye but at $10 \times$ minutely serrulate and thus cystidiate, typically concolorous, sometimes with a faint greyish line or with a distinct black to brown-black margin on some but not all lamellae, in mature specimens often appearing smooth when the marginal cystidia are collapsed. LAmELlulae typically 3 ( 2 short, 1 moderately long) between lamellae, at times up to 7 ( 4 short, 2 moderately long, 1 long). STIPE 20-47 $\mathrm{mm}$ long, 1-2 $\mathrm{mm}$ broad at apex, $2-4.0 \mathrm{~mm}$ broad at base, subclavate, \pm shiny, glabrous, at first dark violet or bluish grey (18-19F3) quickly becoming grey or dark brownish grey ( $5 \mathrm{~F} 1$ to $6 \mathrm{~F} 2$ ) but with a bluish grey tinge, glabrous, hollow, cartilaginous, relatively fragile; basal tomentum white, scarce to moderate. BRUISING REACTIONS absent. 


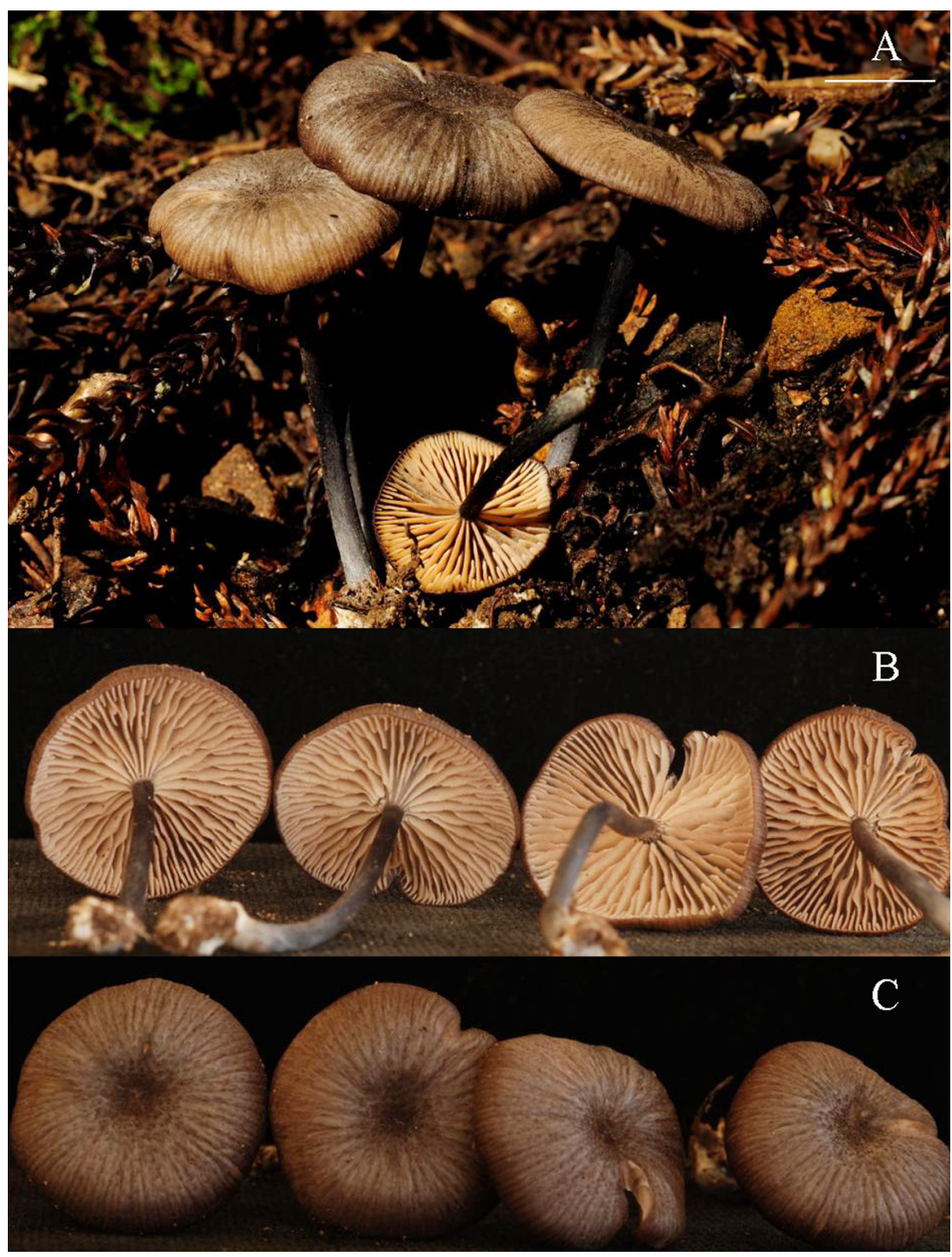

Plate 7. Leptonia poliopus \{DLL 10209a)\}. A: Basidiomata field (1.5); B: Lamellae; C: Pileal surface. $\operatorname{Bar}(\mathrm{A}-\mathrm{C})=10 \mathrm{~mm}$.

BASIDIOSPORES 5-6-angled, angles distinct, apex typically with a single rounded angle, nearly heterodiametric to typically heterodiametric in profile and dorsiventral view, $8.5-13.5 \times 6.0-9.4 \mu \mathrm{m}(x=10.6 \pm 1.0 \times 7.8 \pm 0.6 \mu \mathrm{m}$; $\mathrm{E}=1.1-1.8 ; \mathrm{Q}=1.40 \pm 0.12 ; \mathrm{N}=144 / 4)$. BAsIDIA broadly clavate, hardly tapered, 
with abundant granules prior to spore production, $25.9-44.0 \times 7.9-13.1 \mu \mathrm{m}$ $(x=33.4 \pm 4.3 \times 10.3 \pm 1.2 \mu \mathrm{m} ; \mathrm{E}=2.54-4.10 ; \mathrm{Q}=3.27 \pm 0.42 ; \mathrm{N}=48 / 3) ;$ 2 or 4 -sterigmate, sterigma up to $6.0 \mu \mathrm{m}$ long. CHEILOCYSTIDIA as terminal cells of branched hyphae in the hymenophore, abundant and forming a sterile layer, typically colorless but in $3 \% \mathrm{KOH}$ with a brownish cytoplasmic pigment in specimens with marginate edges, broadly clavate to clavate, $27.2-67.1 \times$ $10.7-20.9 \mu \mathrm{m}(x=41.6 \pm 11.7 \times 14.4 \pm 2.7 \mu \mathrm{m} ; \mathrm{E}=2.9-5.0 ; \mathrm{Q}=2.9 \pm 0.8 ; \mathrm{N}=26 / 3)$ or rarely cylindro-clavate and then $21.3-67.1 \times 4.9-10.1 \mu \mathrm{m}(x=41.1 \pm 10.5 \times$ $7.9 \pm 1.6 \mu \mathrm{m} ; \mathrm{E}=2.3-9.2 ; \mathrm{Q}=5.5 \pm 2.0 ; \mathrm{N}=31 / 4)$, both clavate and cylindroclavate cystidia present in same specimen (DLL 10209a and DLL 10209c) or cylindro-clavate entirely (DLL 10209b). Pleurocystidia absent. LAMELlar TRAMAL HYPHAE subparallel, with rounded to \pm straight end cells, 76.9-291.1 $\times 5.7-19.1 \mu \mathrm{m} ; \mathrm{E} 4.6-23.4 ; \mathrm{N}=12 / 2$ ). Pileipellis always a palisadoderm in the pileus disc, an entangled layer of hyphae with inflated terminal cells, at times with the terminal 2 to 3 cells inflated, 66-125 $\mu$ m deep. Pileocystidia in the disc broadly clavate, rarely nearly napiform, often long clavate, 33.6-99.4 $\times 14.2-29.9 \mu \mathrm{m}(x=54.8-15.1 \times 20.4 \pm 4.5 \mu \mathrm{m} ; \mathrm{E}=1.6-6.3$; $\mathrm{Q}=2.8 \pm 1.1$; $\mathrm{N}=25 / 2$ ). Pileal tramal hyphae similar to those of the lamellar trama, 91-272 $\times 4-20 \mu \mathrm{m} ; \mathrm{N}=6 / 1$. Oleiferous hyPHAE rare in the lamellar trama. Lipoid globules absent. Brilliant Granules absent. Pigmentation plasmatic, brownish in the pileipellis; absent to faintly brownish to brownish in the cheilocystidia. Clamp CONNECTIONS absent in all tissues.

ECOLOGY \& DISTRIBUTION - Several basidiomes frequently encountered in leaf humus or in bare soil under ferns or among rocks along the edge of the trail; basidiomes in one collection scattered, often gregarious. In early May 2011, numerous basidiomes (8-20 per collection) were found in Strickland State Forest in soil and humus and in protected areas near creeks, tracks, or roads.

Additional collections examined - AUSTRAlia. New South Wales, central Hunter District, Strickland State Forest, Lower Parking Lot. Within $20 \mathrm{~m}$ of $33^{\circ} 22^{\prime} 45^{\prime \prime} \mathrm{S}$ $151^{\circ} 19^{\prime} 32^{\prime \prime}$ E, 7 May 2011, DL Largent10209a, 10209b, 10209c.

Distinctive CHARACTERs - Greyish brown pileus, striate to the disc; pallid to off-white lamellae with concolorous or black to brown-black margins; bluish

TABLE 2. Comparison of macromorphology and micromorphology of

Leptonia poliopus collections

\begin{tabular}{lllc}
\hline \multirow{2}{*}{ Collection } & LAMELlar MARgin & \multicolumn{2}{c}{ Basidiospore (average) } \\
Largent 10209a & Colorless, serrulate & $11.0 \mu \mathrm{m}$ & $8.0 \mu \mathrm{m}$ \\
Largent 10209b & Black, smooth & $10.4 \mu \mathrm{m}$ & $7.6 \mu \mathrm{m}$ \\
Largent 10209c & Black, serrulate & $10.0 \mu \mathrm{m}$ & $7.5 \mu \mathrm{m}$ \\
\hline
\end{tabular}




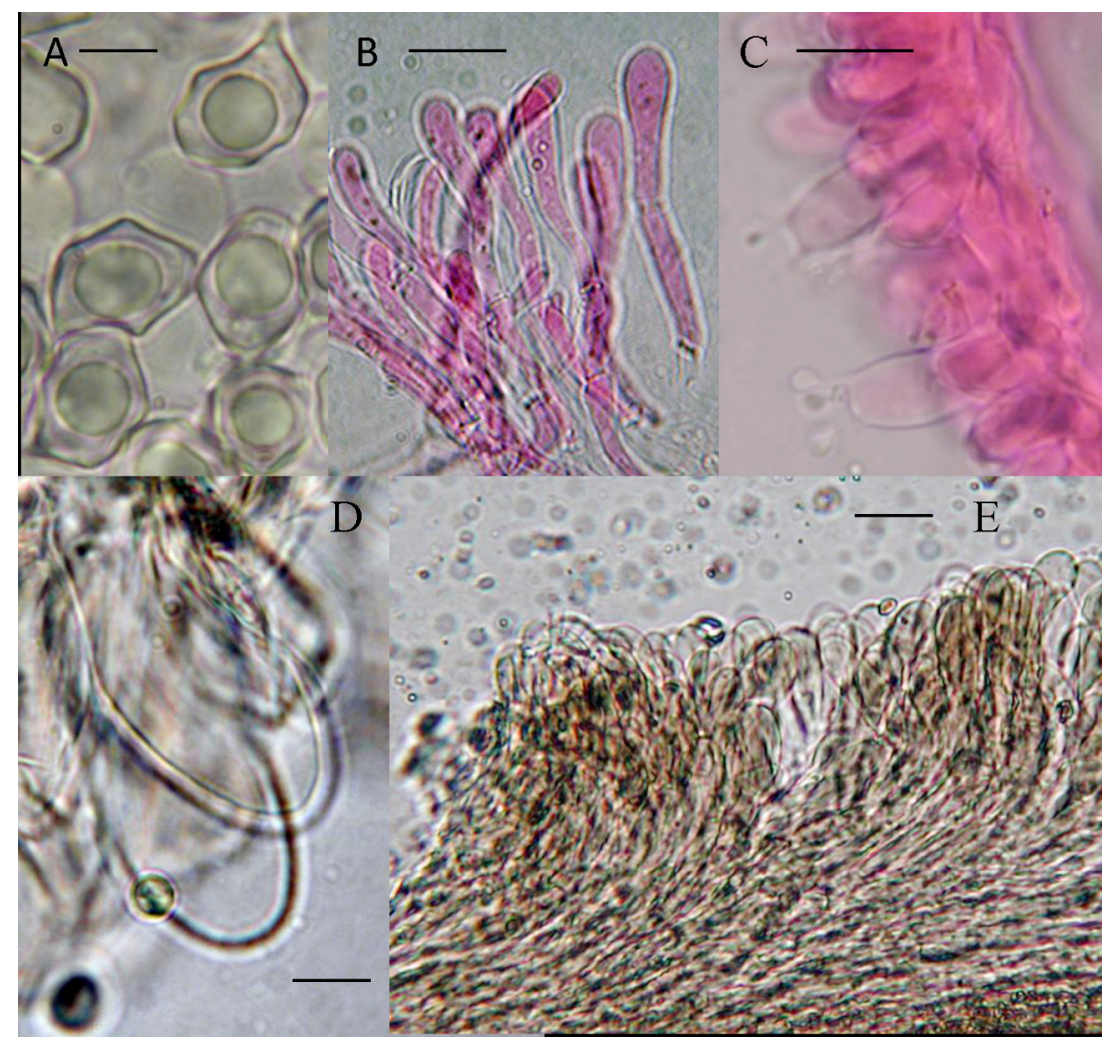

Plate 8. Leptonia poliopus \{DLL 10209b A, C-E; DLL 10209c B\}. A: Basidiospores; B: Cheilocystidia; C: Basidia; D: Pileocystidia; E: Palisadoderm on pileal disc. Bars: $A=5 \mu \mathrm{m} ; \mathrm{B}-\mathrm{C}=15 \mu \mathrm{m}$; $\mathrm{D}=10 \mu \mathrm{m} ; \mathrm{E}=25 \mu \mathrm{m}$.

grey to dark violet stipe that quickly becomes grey to brownish grey; 5-6-angled, heterodiametric basidiospores measuring 8.5-13.5 ×6.0-9.4 $\mu \mathrm{m}$ and averaging $>10 \mu \mathrm{m} \times<8.0 \mu \mathrm{m}$; clavate to broadly clavate cheilocystidia; clampless hyphae.

Comments - Three collections of Leptonia poliopus were made in Strickland State Forest, each differing in the lamellar margin characteristics, type of cheilocystidia, and average basidiospore size (TABLE 2). As overall sequence similarity from all three loci was $100 \%$, we conclude that these three collections represent the same taxon. The composite description above is drawn from the three collections and matches descriptions of European collections that may form concolorous or brown- marginate lamellar edges (Noordeloos 1992, 2004). 
Entoloma asprellopsis G.M. Gates \& Noordel. from Tasmania also shows the same lamellar margin variations but differs from L. poliopus in its bluegrey lamellae and slightly smaller $(9-12 \times 6-8 \mu \mathrm{m})$ basidiospores. Entoloma griseosquamulosum G.M. Gates \& Noordel. differs by its smaller basidiospores, concolorous lamellar edges, a pileus margin that is opaque or only translucentstriate at the very edge, and a saliva-inducing taste (Noordeloos \& Gates 2012). Entoloma asprelloides G. Stev. from New Zealand and E. fuscomarginatum (Cleland) E. Horak (nom. illegit.) and E. fuscum (Cleland) E. Horak from Australia all have similar-sized basidiospores but differ from L. poliopus by their concolorous pileus and stipe (Horak 1973, 1980). Additionally, E. fuscomarginatum (as "rubromarginatum") and E. fuscum lack cheilocystidia (Grgurinovic 1997). Other taxa with features similar to L. poliopus are discussed at the end of the descriptions for E. saponicum, E. asprellopsis, and E. griseosquamulosum (Noordeloos \& Gates 2012),

Leptonia poliopus is not easy to differentiate from other species, in part because of the large number of morphologically similar species (Horak 2008: 186; Largent 1994: 146-152; Noordeloos 2008: 114; Noordeloos \& Gates 2012: 287). Phylogenetic analyses should help to clarify species boundaries in future studies.

Leptonia umbraphila (Noordel. \& Hauskn.) Largent, comb. nov.

Plates 9-10

MycoBAnk MB 802809

હEntoloma umbraphilum Noordel. \& Hauskn., Fungal Diversity 27: 134 (2007).

Pileus $8-25 \mathrm{~mm}$ broad, 2-4 $\mathrm{mm}$ high; opaque and not translucent nor hygrophanous; broadly convex to convex, umbilicate; tomentulose on the disc, squarrulose to appressed squamulose towards the margin, appressed fibrillose on the margin; at first disc very dark brown (7F2) elsewhere a bit lighter (7F4), then becoming dark brown (6-7F5-6), and eventually fading to medium brown (6-7E-F5-6), dull, striate nearly to the disc; margin incurved to decurved, striate, even becoming crenulate with age. TASTE distinctly farinaceous, at times latent. Odor faintly but distinctly farinaceous. LAMELLAE $4.5-9 \mathrm{~mm}$ long, $1.25-5 \mathrm{~mm}$ high, adnate with decurrent tooth to subdecurrent, close to subdistant then distant in over-mature basidiomes, narrow to moderately broad, in some becoming broad, white to orange white to pallid (5A2) at first then more pinkish with basidiospore maturation; margin in places or entirely roughened to serrulate and distinctly brownish to blackish brown; 3 or 5-7 lamellulae between lamellae (in 2-4 rows, 2-4 short and 1-2 medium or 1 medium long). STIPE 8-30 mm long, $1.0-4.0 \mathrm{~mm}$ broad, equal, glabrous to faintly appressed fibrillose, a bit lighter than the pileus, medium brown (6-7E-F4-6), at times pale orange (5B3) at the apex, hollow and stiff but decays rapidly; basal tomentum scarce. BRUISING REACTIONS absent. 


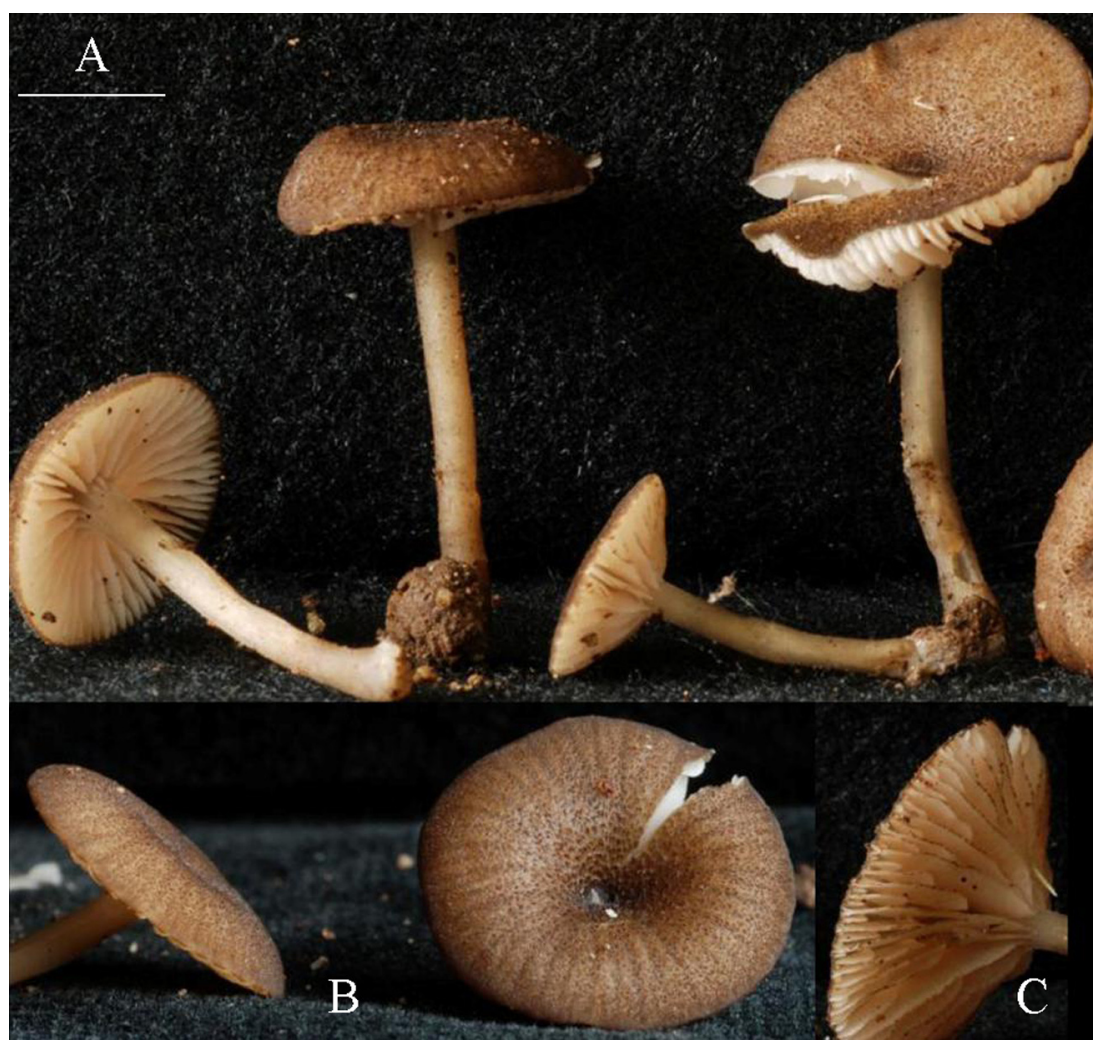

Plate 9. Leptonia umbraphila \{DLL 9792 A; DLL 9793 B-C\}. A: Basidiomata (3); B: Pileal surface (2.5); C: Marginate lamellar edge (2.5). Bar (A- C) $=10 \mathrm{~mm}$.

BASIDIOSPORES typically cuboid in all views, at times 5-angled in dorsi-ventral view, angles distinct, mostly isodiametric but some may be heterodiametric, relatively small, $5.5-8.3 \times 5.5-7.9 \mu \mathrm{m}(x=7.3 \pm 0.50 \times 6.7$ $\pm 0.52 \mu \mathrm{m} ; \mathrm{E}=1.00-1.41 ; \mathrm{Q}=1.10 \pm 0.09 ; \mathrm{N}=92 / 4)$. BAsidia mostly $1-2-$ sterigmate, rarely 4 -sterigmate, subclavate with the very base tapered, sterigma $2.1-4.8 \mu \mathrm{m} ; 22.5-40.6 \times 6.5-11.0 \mu \mathrm{m}(x=28.6 \pm 3.8 \times 8.5 \pm 0.9 \mu \mathrm{m} ; \mathrm{E}=2.8-4.5$; $\mathrm{Q}=3.4 \pm 0.4 ; \mathrm{N}=40 / 3)$; base $1.6-4.5 \mu \mathrm{m}$. CheIlocystidia clavate, scattered to abundant, in clusters but not forming a sterile layer along the entire lamella, clavate, $23.3-53.5 \times 5.1-10.7 \mu \mathrm{m}(x=37.5 \pm 9.1 \times 8.1 \pm 1.8 \mu \mathrm{m} ; \mathrm{E}=2.3-7.9$; $\mathrm{Q}=4.8 \pm 1.3 ; \mathrm{N}=16 / 2)$. Pleurocystidia absent. Lamellar Tramal Hyphae relatively slender and thus not broad, 40.8-144.1 $\times 2.2-22.0 \mu \mathrm{m}(\mathrm{N}=26 / 3)$. Pileipellis badissima-type (laterally agglutinated hyphae abundant; slender cylindro-clavate collapsed on clavate to vesiculate pileocystidia), 80-135 $\mu \mathrm{m}$ 


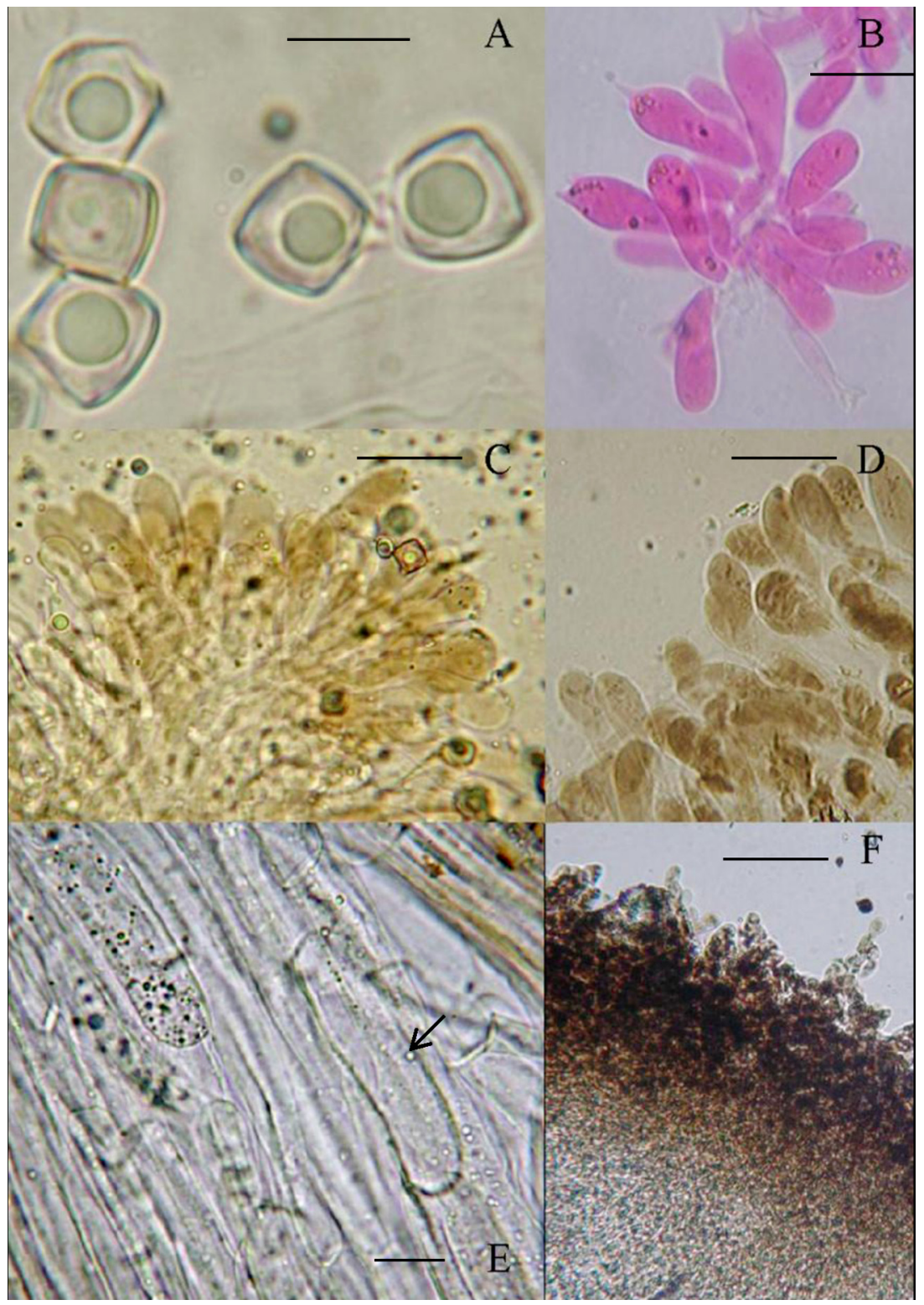

Plate 10. Leptonia umbraphila \{DLL 9629 A-E; DLL 9792 F\}. A: Basidiospores; B: 1-2 sterigmate basidia; C: Clavate cheilocystidia with brownish cytoplasmic pigment; D: Pileipellis, pileocystidia and cytoplasmic plaque-like pigment; E: Pileal trama with brilliant granules and parietal pigment (arrow); F: Pileipellis. Bars: $A=7 \mu \mathrm{m} ; \mathrm{B}=20 \mu \mathrm{m} ; \mathrm{C}=30 \mu \mathrm{m} ; \mathrm{D}=20 \mu \mathrm{m} ; \mathrm{E}=\mu \mathrm{m} ; \mathrm{F}=65 \mu \mathrm{m}$. 
deep on the disc. Pileocystidia cylindro-clavate to clavate to vesiculate, $22.7-68.6 \times 4.8-17.3 \mu \mathrm{m}(x=36.3 \pm 12.9 \times 10.8 \pm 3.6 \mu \mathrm{m} ; \mathrm{E}=1.6-9.4$; $\mathrm{Q}=4.0 \pm 2.4 ; \mathrm{N}=19 / 2)$. Pileal tramal hyphaE relatively short, subparallel, 32.5-113.1 $\times$ 4.4-15.4 $\mu \mathrm{m}$. STIPITIPELlis a cutis. BAsidiole clusters rare, 29.7-44.8 $\times 8.2-17.0 \mu \mathrm{m}(\mathrm{N}=8 / 1)$. STIPE TRAMAL hyphaE subparallel, 31.5-191.7 $\times 4.4-15.4 \mu \mathrm{m}(\mathrm{N}=11 / 2)$. Oleiferous hyphaE scattered in the stipe trama. Lipoid Globules absent. Brilliant granules abundant and small in the basidia and in the pileal tramal hyphae. Pigmentation pale brown, uniformly intracellular in the cheilocystidia; very dark brown, intracellular, and in pigment-globules in the hyphae of the pileipellis, not soluble in $3 \% \mathrm{KOH}$ or in water. Clamp CONNECTIONS absent in all tissues.

ECOLOGY \& DISTRIBUTION - Scattered in bare soft soil in areas protected and shaded by a dense tree overstory, Mossman National Park; in bare compacted soil shaded by a single tree (but protected by roots) in middle of Emmagen Creek Trail, Daintree National Park; late February to late March.

\begin{abstract}
Additional collections examined - AUSTRALIA. Queensland, Cook Region, Mossman National Park, $16^{\circ} 28^{\prime} 15.2^{\prime \prime}$ S $145^{\circ} 19^{\prime} 48.8^{\prime \prime}$ E, 27 February 2009, DL Largent 9629, 9630; $16^{\circ} 28^{\prime} 15.2^{\prime \prime} \mathrm{S} 145^{\circ} 19^{\prime} 48.8^{\prime \prime} \mathrm{E}, 9$ March 2009, DL Largent 9640; $16^{\circ} 28^{\prime} 15^{\prime \prime} \mathrm{S}$

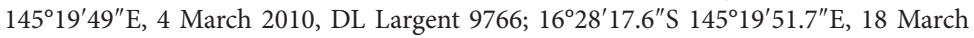
2010, DL Largent 9792, 9793, 9799. Daintree National Park, Tribulation Section, $16^{\circ} 02^{\prime} 20.1^{\prime \prime} \mathrm{S} 145^{\circ} 27^{\prime} 40.8^{\prime \prime} \mathrm{E}, 22$ March 2010, DL Largent 9816.
\end{abstract}

Distinctive CHARACTERS -Small broadly convex-depressed dark brown pileus; weakly decurrent or subdecurrent lamellae; basidiospores cuboid or 5-angled, isodiametric, and averaging $<8.1 \mu \mathrm{m} \times<7.5 \mu \mathrm{m}$; badissima-type pileipellis with dark brown, intracellular, pigment globules; basidia small, typically 2-sterigmate; clavate, cheilocystidia with pale brownish pigment.

Comments - The collections of L. umbraphila from northern Queensland are identical to the Seychelles holotype in habitat, all macrofeatures, and nearly all microfeatures. In the holotype (Noordel. \& Hauskn. 2007 as E. umbraphilum), the basidiospores are a little larger $(7-9 \times 6.5-8.5 \mu \mathrm{m})$, the basidia are slightly smaller $(23-31 \times 8-11 \mu \mathrm{m})$, and the cheilocystidia somewhat smaller $(20-30$ $\times 8-11 \mu \mathrm{m})$ than in the northern Queensland collections. We consider these slight differences to be insignificant.

Rhodophyllus dicubospermus Romagn. \& Gilles from Gabon closely resembles L. umbraphila with its omphalinoid stature, brown pileus and stipe, bisporic basidia, and cuboid basidiospores but differs in the reddish brown pileus, brownish white lamellae, concolorous lamellar margin, and slightly larger $(6.5-9 \times 6.2-8 \mu \mathrm{m})$ basidiospores (Romagnesi \& Gilles 1979).

\title{
Acknowledgments
}

The Largent family trust provided support for the fieldwork and we are grateful to Pamela Largent for support and collections. The Australian Tropical Herbarium and 
the School of Marine and Tropical Biology, James Cook University, provided fieldwork and logistical support. The DNA sequences generated in this study are based upon work supported by the National Science Foundation under Grant No. DRI 0922922 awarded to Sarah Bergemann. Comments by the two reviewers, Drs. Timothy J. Baroni and Terry W. Henkel, and by the nomenclature editor, Dr. Shaun Pennycook, were also beneficial. We wish to thank Peter Newling, Pam O'Sullivan, and Skye Moore for their collections and descriptions.

\section{Literature cited}

Baroni TJ, Halling R. 2000. Some Entolomataceae (Agaricales) from Costa Rica. Brittonia 52: 121-135. http://dx.doi.org/10.2307/2666502

Baroni TJ, Matheny B. 2011. A re-evaluation of Gasteroid and Cyphelloid species of Entolomataceae in eastern North America. Harvard Papers in Botany 16: 293-310. http://dx.doi.org/10.3100/0.25.016.0205

Co-David D, Langeveld D, Noordeloos ME. 2009. Molecular phylogeny and spore evolution of Entolomataceae. Persoonia 23: 147-176. http://dx.doi.org/10.3767/003158509X480944

Dennis RWG. 1953. Les Agaricales de l'Ile de la Trinité. Rhodosporae-Ochrosporae. Bulletin de la Société Mycologique de France 69: 145-198.

Grgurinovic C. 1997. Larger fungi of South Australia. The Botanic Gardens of Adelaide and State Herbarium and the Flora and Fauna of South Australia Handbooks Committee: Adelaide.

Horak E. 1973. Fungi Agaricini Novaezelandiae I-V. Beihefte Nova Hedwigia 43: 1-200.

Horak E. 1980. Entoloma (Agaricales) in Indomalaya and Australasia. Beihefte zur Nova Hedwigia 65: $1-352$.

Horak E. 1982. Entoloma in South America II. Sydowia. 35: 75-99.

Horak E. 2008. Agaricales of New Zealand. 1: Pluteaceae (Pluteus, Volvariella) Entolomataceae (Claudopus, Clitopilus, Entoloma, Pouzarella, Rhodocybe, Richoniella). Fungi of New Zealand Volume 5. Fungal Diversity Research Series 19: 1-305.

Kornerup A, Wanscher JH. 1978. Methuen handbook of colour, 3rd ed. Richard Clay Ltd: Chichester, Sussex.

Largent DL. 1994. Entolomatoid fungi of the western United States and Alaska. Mad River Press Inc: Eureka, California.

Largent DL, Abell-Davis SE, Cummings GE, Ryan KL, Bergemann SE. 2011a. Saxicolous species of Claudopus (Agaricales, Entolomataceae) from Australia. Mycotaxon 116: 253-264. http://dx.doi.org/10.5248/116.253

Largent DL, Bergemann SE, Cummings GE, Ryan KL, Abell-Davis SE, Moore S. 2011b. Pouzarella (Agaricales, Entolomataceae) from New South Wales (Barrington Tops National Park) and northeastern Queensland. Mycotaxon 117: 435-483. http://dx.doi.org/10.5248/117.435

Largent DL, Bergemann SE, Abell-Davis SE, Kluting KL, Cummings GA. 2013. Three new Inocephalus species with cuboid basidiospores from New South Wales and Queensland, Australia. Mycotaxon 123: 301-319. http://dx.doi.org/10.5248/123.301.

May TW, Wood AE. 1997. Catalogue and bibliography of Australian macrofungi 1. Basidiomycota. Fungi of Australia Vol. 2A. Australian Biological Resources Study: Canberra.

Murrill WA. 1911. The Agaricaceae of tropical North America, IV. Mycologia 3: 271-282. http://dx.doi.org/10.2307/3753496

Noordeloos ME. 1992. Entoloma s.l. Fungi Europaei vol. 5. Ed. Candusso: Alassio, Italy.

Noordeloos ME. 2004. Entoloma s.l. Fungi Europaei vol. 5a. Ed. Candusso: Alassio, Italy, 
Noordeloos ME. 2008. Entoloma in North America 2: the species described by C. H. Peck - type studies and comments. Österreichische Zeitschrift für Pilzkunde. 17: 87-152.

Noordeloos ME, Gates GM. 2012. The Entolomataceae of Tasmania. Fungal Diversity Research Series 22: 1-399. http://dx.doi.org/10.1007/978-94-007-4679-4

Noordeloos ME, Hausknecht A. 2007. The genus Entoloma (Basidiomycetes, Agaricales) of the Mascarenes and Seychelles. Fungal Diversity 27: 111-144.

Romagnesi H, Gilles G. 1979. Les Rhodophylles des forêts côtières du Gabon et de la Côte d'Ivoire avec une introduction générales sur la taxinomie du genre. Beihefte zur Nova Hedwigia 59: 1-649.

Thiers B. 2012. Index Herbariorum: A global directory of public herbaria and associated staff. New York Botanical Garden's Virtual Herbarium. http://sweetgum.nybg.org/ih/ [accessed November 2012] 